\title{
The Ottawa Convention Banning Landmines, the Role of International Non-governmental Organizations and the Idea of International Civil Society
}

\author{
Kenneth Anderson*
}

\begin{abstract}
Establishment of the Ottawa Convention Banning Landmines was regarded by many international law scholars, international activists, diplomats and international organization personnel as a defining, 'democratizing' change in the way international law is made. By bringing international NGOs — what is often called 'international civil society' — into the diplomatic and international law-making process, many believe that the Ottawa Convention represented both a democratization of, and a new source of legitimacy for, international law, in part because it was presumably made 'from below.' This article sharply questions whether the Ottawa Convention and the process leading up to it represents any real 'democratization' of international law, challenges the idea that there is even such a thing as 'international civil society,' at least in the sense that it is democratic and comes 'from below,' and disputes that there can be such a thing as 'democratic' processes at the global level. It suggests, by way of alternative, that the Ottawa Convention and the process leading up to it should be seen as a step in the development of global transnational elites at the expense of genuinely democratic, but hence local, processes.

\footnotetext{
* Associate Professor of Law, Washington College of Law, American University, Washington, DC; kanders@wcl.american.edu. Mr Anderson was previously Director of the Human Rights Watch Arms Division and General Counsel to the Open Society Institute-Soros Foundations. He currently chairs the advisory board of the Open Society Institute Landmines Project, which funds activities in support of the international NGO campaign to ban landmines, and is a member of the advisory board of the Human Rights Watch Arms Division. Views expressed are strictly his own. Thanks as ever to David Rieff and John Ryle, and particular thanks to Jack Simon for taking over child care duties for his grandniece, Renee, while this article was being completed.
}

EJIL (2000), Vol. 11 No. 1, 91-120 


\section{Introduction: A Sea-Change in the International Legal Order?}

For many whose professional work is international public law and policy, the most significant legal events of the entire 1990s were the signing of the Landmines Treaty (the Ottawa Convention) ${ }^{1}$ and the signing of the International Criminal Court (the ICC) statute (the Rome Statute). ${ }^{2}$ Even recognizing other key legal events during the decade, such as the establishment of the ad hoc Yugoslavia and Rwanda war crimes tribunals, $^{3}$ for many the Ottawa Convention and the Rome Statute especially epitomized fundamental changes in the nature of the international legal system changes that in a hundred years, perhaps, would be seen as the critical beginnings of a new international system.

This enthusiasm is easy to understand. The Ottawa Convention represents the first time in over a century in which a major, traditional weapon system has been banned outright and not simply regulated in its use, by a treaty that has broad participation by states. Moreover (and conceptually still more importantly) the Ottawa Convention represents, especially to the NGO activist community, the victory of what nongovernmental organizations (NGOs) and now many others call international civil society ${ }^{4}$ - the successful entry of international non-governmental organizations (NGOs) into diplomatic and lawmaking processes that hitherto have been reserved largely to states and international organizations, represented by officially recognized and accredited diplomats. It is, according to this view of things, the 'democratization of international law'. ${ }^{5}$

The Rome Statute, for its part, represents in the minds of its supporters - and especially for the international NGOs - the establishment of the rule of law in the international community, solidified with a prosecutor, judges, and criminal sanctions against individuals rather than morally more opaque sanctions against states. ${ }^{6}$ It is -

1 Convention on the Prohibition of the Use, Stockpiling, Production and Transfer of Anti-Personnel Mines and on Their Destruction (the 'Ottawa Convention'), 36 ILM (1997) 1507, entered into force 1 March 1999.

2 Rome Statute of the International Criminal Court (the 'Rome Statute'), 37 ILM (1998) 999, adopted by the United Nations Diplomatic Conference of Plenipotentiaries on the Establishment of an International Criminal Court, 17 July 1998.

3 See generally Y. Beijbeder and T. van Boven, Judging War Criminals: The Politics of International Justice (1999).

4 See discussion at Part 2, Section B, supra.

5 Ibid.

6 For a representative view from a prominent international NGO activist, see A. Neier, War Crimes: Brutality, Genocide, Terror, and the Struggle for Justice (1998). Neier is president of the Open Society Institute and was formerly executive director of Human Rights Watch. Kenneth Roth, the current executive director of Human Rights Watch, has said in conferences and meetings in 1998-1999 that the formation of the International Criminal Court is the most important advance in international human rights of the 1990s. See also, among many similar statements from Human Rights Watch and the numerous other international NGOs who formed the NGO coalition in favour of the ICC, Ken Roth, Memorandum to Human Rights Watch Board, Advisory Committees, Council, and Friends and Supporters, 'Advisory on HRW's Campaign for an International Criminal Court', describing the ICC as 'one of Human Rights Watch's most important priorities', 11 August 1998. 
for those who believe that the Rome Statute will work out as planned, at least - the realization of what for so long had been merely the utopian aspirations of those for whom only the true political legitimacy is international legitimacy and for whom merely sovereign states are something whose historical time is past, except as constitutionally subsidiary entities within the larger empire of world governance through the global rule of law. ${ }^{7}$ The Rome Statute stands, in the minds of its enthusiasts, for the proposition that justice is universal and that universalism's supreme expression must be international; it stands for the sovereignty of international justice over other institutions. ${ }^{8}$

The importance of these two treaties thus appears considerable: presumably, according to their supporters, they epitomize the democratization of international law, on the one hand, and the assertion of its genuine sovereignty over all other assertions of sovereignty, on the other. I say this as someone who has laboured long as an activist on behalf of the Ottawa Convention, but who fully (and perhaps surprisingly) opposes the scope and aspirations of the Rome Statute. ${ }^{9}$ Even as someone, in other words, who is without sympathy for what I regard as the imperial agenda of international law, ${ }^{10}$ I nonetheless acknowledge these two treaties as critical, perhaps the critical, legal events of the first post-Cold War decade.

Nevertheless, it is possible to be sceptical of the factual assertion that these treaties have such grandiose importance. One can doubt that they indeed represent watershed events in the history of international order and organization. The principal basis for this scepticism - the fly in the ointment, so to speak, of this putatively 'realized utopianism' - is simply that the United States has stood aside from each of these

7 For example, Neier writes with respect to the ICC, the ICC would have a "mandate to deal with those who commit crimes within its jurisdiction whether they are from small states in Central Europe or Central Africa or from the richest and most powerful nations on earth'. Neier, ibid. at 259.

8 The literature written by international lawyers in support of this proposition is voluminous; representative of it within the past several years are Neier, ibid.; M.F. Harris et al., Making Justice Work: The Report of the Century Foundation/Twentieth Century Fund Task Force on Apprehending Indicted War Criminals (1998); Y. Beigbeder and T. Van Boven, Judging War Criminals: The Politics of International Justice (1999); J.R.W.D. Jones, The Practice of the International Criminal Tribunals for the Former Yugoslavia and Rwanda (1998); H. Ball, Prosecuting War Crimes and Genocide: The Twentieth Century Experience (1999); and R. Stenson and M. Sann (eds), The Prosecution of International Crimes (1996). One might also usefully consult the voluminous reports and press releases reflecting this theme from Human Rights Watch, available at www.hrw.org

9 Some examples of American opposition to the ICC include Frum, 'The International Criminal Court Must Die', The Weekly Standard (Washington DC), 10/17 August 1998, at 27; Helms, 'Personal View: Jesse Helms: Voting Against the International Criminal Court is Not Enough. The US Should Try To Bring It Down', The Financial Times, 31 July 1998, at 18. A thoughtful discussion of shortcomings of the current ICC statute by a prominent American expert in human rights and humanitarian law — and certainly no enemy to the idea of an international criminal court - is found at Meron, 'The Court We Want', Washington Post, 13 October 1998, at A15; for a version of the standard moralizing lecture directed at Washington DC from Europe for its failure to join the Rome Statute, see The Economist, 'World Law and World Power' (US ed.), 5 December 1998, at 16. A different critique of the ICC is made by a non-American, Sellars, 'The Tyranny of Human Rights', Spectator (London), 28 August 1999, at 11; she argues that 'war-crimes tribunals advance the global aims of Western leaders'.

10 See discussion at Part 1, supra. 
treaties. It has joined neither the Ottawa Convention nor the Rome Statute, and it appears unlikely that it will do so in the foreseeable future. ${ }^{11}$ This inconvenient fact raises a problem for those who want to see these treaties as a sea-change, desirable or not, in the nature of international order: expressed brutally, what profound change can these treaties purport to signal if the largest and most powerful state, the world's only superpower, the only military power capable of projecting force across the globe, stands aside from them?

This paper attempts a preliminary assessment of one aspect of this problem - how to understand the role of the international NGOs that have driven so much of the debates leading to these two treaties, and which have proven to be the indispensable interlocutors of the United States in its refusal to join either treaty-interlocutors, in some respects, even more important than other governments in the negotiations. The discussion will be limited to the Ottawa Convention, but the analysis has certain implications for the Rome Statute. In the course of this assessment, however, it suggests a sharply different way of thinking about the Ottawa Convention and, by implication, the Rome Statute, and the processes that led to them, than is typically held among those who pay attention to public international law and policy. In focusing on how to understand the participation of international NGOs as advocates campaigning for and negotiating these treaties, it devolves on to the question of the role and meaning of 'international civil society'.

It should be understood at the outset, however, that these remarks are necessarily speculative. It is far too soon to know the real effects of either the landmines ban or the ICC, the effects of the United States remaining outside these regimes, or even whether the United States will remain outside. It is far too soon to know whether either of these treaties will permanently achieve its stated goals or even see its mechanisms put into place in a stable way. And if that is too soon to know, it is likewise too soon to know whether these treaties indeed represent any kind of sea-change in how international law is made and how the international system works.

Moreover, the primary materials for knowing what has gone on in the processes of reaching these treaties are still largely oral histories. Very little of those histories have as yet been written down in an analytically historical way, as respectably published sources that one could cite in traditional, academic law journal fashion. For that reason I will freely draw on my personal experiences as an international NGO activist

11 On the US refusal to sign the Ottawa Convention, see Lobe, 'Disarmament: US Considers Signing Landmine Ban By 2006', Inter Press Service, 25 May 1998 ('the administration refused to sign the Ottawa Convention due to strong opposition from the Pentagon'); on background to the US refusal to sign the Rome Statute, see Agence France Presse, 'US Senators plan to oppose ICC, put pressure on signatories', 23 July 1998. Of course, one should never underestimate the vicissitudes of American domestic politics. If the Democratic Party were to win both the White House and Congress in the next election, Senator Jesse Helms (R-NC) were to die, and the Korean peninsula peacefully to reunify, then matters might be different. 
during the years leading up to the Ottawa Convention. ${ }^{12}$ It should be understood, of course, that other participants in those events will have sharply different understandings and interpretations of what went on - understandings and interpretations that will often be far more consonant with the celebratory mood accompanying both the Ottawa Convention and the Rome Statute among those who agitate for what I will here describe as 'international legal imperialism'.

These observations will be offered as modest but, I believe, vital evidence of a broad thesis about international NGOs and their function in the current international system. I give an interpretation of the way in which the Ottawa Convention came into being, in the form of 'seven lessons' of the campaign to ban landmines, with particular attention to the role of international NGOs and their relationship with international organizations and sympathetic states. The nature of this relationship I will describe as a 'romance', and suggest that it carries with it some dubious consequences. Having made this commentary on the campaign, I turn to give a broader reading of the meaning of the campaign as a critical commentary on two crucial ideas. The first is the widespread belief that international NGOs constitute a kind of 'international civil society', one which functions in a way analogous to 'civil society' within a settled domestic society. The second is an interpretation of the relationship between international NGOs and international organizations, characterizing it as one of mutual legitimation; with respect to international organizations, international NGOs are cast in the role of giving some veneer of democratic legitimacy to an international system that, in my view, suffers from a permanently incurable democratic deficit.

We cannot turn to these themes, however, without a brief consideration of the perhaps peculiar methodology that this article pursues. ${ }^{13}$

\section{Liberal Internationalism or ‘Two Imperialisms' or Both?}

\section{A A Brief Note on Methodological Prejudices}

Before setting upon the crooked path by which I hope to illuminate the meaning of US unilateralism or, better said, non-participation in the Ottawa Convention, we ought

12 I do not have the same extensive personal experience with the Rome Statute and the campaign leading up to it. Moreover, its 'inner' history — by this I mean the subjective but critically important tone, tenor, and aspirational mood of the campaign for the treaty, especially among the international NGOs, whether of the Rome Statute or the Ottawa Convention - is even less a matter of written record at this point in time than that of the Ottawa Convention. By contrast, in the case of the Ottawa Convention, I believe I have a personal understanding of both the exterior and interior history of the campaign to ban landmines that - even in a subjective and, to be sure, disputable way - carries some independent weight even where I am reporting on my own personal experience.

13 The discussion of methodology in Part 2 may strike some as far afield from the issue of landmines and the Ottawa Convention; my presentation and subsequent discussions with participants in the University of Michigan Law Conference on Unilateralism at which this paper was first presented convince me, however, that it is crucial to understanding what comes after it. Certainly participants in the conference agreed with that assessment. 
first to sound the cautionary note that the issue of the United States abroad in the world is not merely one of power. It is instead one of moral and political legitimacy. For many it is consoling to believe that when the United States acts alone, acts contrary to what many or even most other states would have it do, and acts contrary to those states that have traditionally extruded themselves ${ }^{14}$ as the world's conscience, it acts merely from the surety of its own power. The United States' ability to act contrary to others is, according to this consolation, merely a matter of power, guns and butter, its arrogance and obduracy. Such sentiments emerge when, for example, the US is accused, upon its failure to join the Ottawa Convention, the Rome Statute, or for that matter the Convention on the Rights of the Child ${ }^{15}$ or other treaties that have obtained broad or even nearly total (if perhaps merely rhetorical) ratification, of consorting with 'rogue states'16 — Libya, Iran, Iraq, North Korea, the whole shifting club of rogues — or, still more provocatively, of being a rogue state itself. ${ }^{17}$

But however consoling, it is a stupidity. ${ }^{18}$ Admittedly it is one in which I have indulged; as an activist seeking to shame the United States into joining the Ottawa Convention, I have on occasion accused the United States of being no better in this

14 In lieu of GDP, as it were, recalling Stendhal: 'That sort of fellow [Rousseau] wishes to argue about everything, and has not a thousand crowns a year.' Stendhal, The Red and the Black (2nd ed. 1984, trans. C.K. Scott Moncrieff) 328.

15 Convention on the Rights of the Child, UN Doc. A/44/49 (adopted by the General Assembly, 20 November 1989; entered into force, 2 September 1990).

16 The most recent prominent place where the 'rogue state' assertion against the United States has appeared is Judt, 'A Superpower Flaunts Its Ignorance', New York Times, 17 October 1999, section 4, p. 17, in which Judt, writing following the US Senate rejection of the Comprehensive Nuclear Test Ban Treaty, declares that 'if we behave like a rogue nation ourselves, smug in our monopoly of virtue and weapons, how can we hope to bring pressure to bear on true rogue nations overseas?' For a standard, US foreign policy establishment-style analysis that frames the issue explicitly in terms of the US as a 'rogue' state, see Manning, 'U.S.: Global Steward or Rogue Power?' The Straits Times (Singapore), 9 November 1999, at 54 ('is the US the steward of global power or a rogue superpower?').

17 Following the October 1999 refusal of the US Senate to ratify the test ban treaty, much commentary erupted, particularly in Europe, in language similar to claims of the US as a 'rogue state'; in particular, French president Jacques Chirac delivered a remarkable speech on 4 November 1999, in which he described the US as a 'hyperpower', and suggested that the European Union could flourish by seeking to supplant the United States; the EU, according to Chirac, needed to consolidate the United Nations and other international institutions to prevent the world from relying on the United States for financial stability, cultural harmony and global security. See Fitchett, 'Chirac's Attack on Congress Has a Bigger Target', International Herald Tribune, 9 November 1999, at 2; Whitney, 'France Presses for Power Independent of the US', New York Times, 7 November 1999, Section 1, p. 9; Hoagland, 'American Menace', The Times (London), 4 November 1999; Graham, 'Chirac Attacks American Attitudes', Financial Times, 5 November 1999, at 10.

18 One could just as easily turn the 'consorting with rogue states' proposition around, with respect to the Rome Statute, for example, as the president of Freedom House, Adrian Karatnycky, did in the Wall Street Journal, noting that the 'U.S. — the world's most important democracy — voted against the [ICC], as did India - the world's largest democracy — and Israel — a state built by the victims of genocide'. Karatnycky, 'Don't Worry, War Criminals — The New Court Won't Work', Wall Street Journal, 27 July 1998, at A15; but see the reply, Kenneth Roth (Executive Director, Human Rights Watch), 'We Need an International Court', Letter to the Editor, Wall Street Journal, 18 August 1998, at A23. But it is a silly point, whichever way one turns it. 
regard than the rogues. ${ }^{19}$ Tempting but untrue, however; the power the United States exercises in the world, for better and for worse, is embedded profoundly in a web of claims to political and moral legitimacy (even if some of those claims are themselves contradictory and competing). It is the world's superpower not merely by strength of its GDP and willingness to spend more than others on guns, but by assertion of these moral and political claims to legitimacy, not merely within its borders, but upon the world stage. One may dislike all or part of the basis of those claims to legitimacy, one may think them specious or otherwise, but anyone imagining that to struggle with US unilateralism, in the name of international legal order or anything else, is merely to struggle with power harbours a serious delusion. ${ }^{20}$ The struggle is inevitably as much or more with ideas as with power; surely this is obvious, but it seems sometimes forgotten in the myopia of wishful and self-righteous internationalist thinking.

To frame the issue as one of US unilateralism, in other words, as against the virtuously internationalist world gets it wrong. While all unilateral US actions threaten the legitimacy of international legal imperialism, some unilateral US actions tend in the direction of US imperialism as an alternative to what I have called 'international legal imperialism', the nascent imperialism, the willingness to impose supranational rule, that is the consequence of assertions of the sovereignty of supranational institutions. Whereas still others - regrettably fewer and fewer in these days of Madeleine Albright ${ }^{21}$ — tend toward an anti-imperialism that, to be sure,

19 I am here partly reflecting self-critically on things I have said during the course of the NGO campaign to ban landmines, in speeches and presentations. But I am also referring to similar remarks that Jody Williams made when she received word that she had received the 1997 Nobel Peace Prize for her work on the international landmines ban campaign; in press interviews she described the US position and President Clinton in terms similar to the 'rogue state'. See Goldberg, 'Peace Prize Goes to Land-Mine Opponents', New York Times, 11 October 1997, at A-1, (quoting Williams, 'I think it's tragic that President Clinton does not want to be on the side of humanity...' and quoting Williams referring to Clinton as 'Billy' and 'a weenie'). At the time Ms Williams made these remarks, I applauded them, despite criticism from others in the ban campaign, notably Vietnam Veterans of America Foundation executive director Robert O. Muller, that such remarks were self-indulgent and failed to capture the deeper, strategically critical understanding that the US position was not merely based on narrow calculation of interest but on a broader ideological view of itself that simply could not be equated with the behaviour of the usual club of rogue states. Indulging oneself in the fiction of thinking that the US was just another rogue state was strategically dangerous for the campaign, a thoughtful senior advisor to the campaign remarked to me privately at the time, because it meant that the campaign would crucially underestimate the strength of the US refusal to sign the Ottawa Convention; better, said this advisor, to understand the US position as a moral position, even if a wrong one, in order to understand the strength with which the US would defend it. I thought at the time this advice was wrong; although I still admire Williams's chutzpah, in retrospect I now think it, and my own repeating of it, was mistaken.

20 My colleague James Boyle points out, too, that the 'rogue' states — Libya, Iran, North Korea, Cuba, etc. — are fundamentally motivated not by pure calculations of power and Realpolitik advantage but by extremely strong, if repellent, ideologies. What makes a rogue state a rogue is not that it acts purely according to calculations of obdurate power but the moral quality of its ideology.

21 Recent biographies of US Secretary of State Madeleine Albright appear to confirm that at bottom she is a believer in supranational institutions — held back by a US Congress and an American people that are not entirely ready to turn sovereignty and security to the brave new world of supranational institutions, nor ready to sacrifice American soldiers to their ideals - but eager to be seen as an architect of a new order. See M. Dobbs, Madeleine Albright: A Twentieth Century Odyssey (1999); A. Blackman, Seasons of Her Life: A 
ought not to be confused with isolationism; they are different. ${ }^{22}$ I favour antiimperialism. ${ }^{23}$ But neither the characterization of an instance of US unilateral action as imperial or anti-imperial, nor the US ability to take unilateral action, is ever free of the simultaneously enabling 'mission' conferred by legitimacy and disabling 'constraint' imposed by legitimacy upon power. It is never the mere exercise of power.

What should be said here, then, of imperialism and anti-imperialism, before turning to the specifics of the international campaign to ban landmines and the US response to it? I have remarked in passing above that supposed US unilateralism must, at this point in time, be understood against two categories of imperialisms: the nascent imperialism of the international legal order, on the one hand, and the 'really existing imperialism', US imperialism, the imperialism of cruise missiles and capital markets, on the other. They are, in my view, in competition or, at least, in potential competition with each other. ${ }^{24}$ The US refusal to join the Ottawa Convention ought to be seen at

Biography of Madeleine Korbel Albright (1998); and the much less objective T. Blood, Madam Secretary: A Biography of Madeleine Albright (1997). It is in this spirit that the 1999 Kosovo War ought to be seen: for Albright and the closet supranationalists of the Clinton administration, the Kosovo War gave them the opportunity to demonstrate the principle of military action for purely humanitarian motives with no discernible national interest; the problem for the supranationalists, however, was that it was fought not by supranational institutions or even with their authorization, but instead by the United States, occasionally assisted by the rest of Nato. For those few US conservatives who supported the Kosovo intervention, it gave the US the opportunity to fight a war without even pretending to obtain the authorization of supranational institutions such as the UN or the Security Council, so to denigrate the authority of such bodies; the problem for these nationalists, however, was that the Kosovo War was not fought for national interest. The two factions favouring the war in the US made a modest alliance, each getting something but each giving something up; each represents a brand of imperialism, one supranationalist imperialism and the other US imperialism.

22 This is a point lost on Patrick Buchanan, in his new manifesto, P. Buchanan, A Republic, Not an Empire: Reclaiming America's Destiny (1999). The republican sentiment of Buchanan's title is admirable, but unfortunately goes no deeper in the book than the title page and is belied by Buchanan's insistence on isolationism, nativism, xenophobia, racism, and an anti-immigrant position as conditions for a republic; those are the conditions for a nation based upon ethnicity, however, rather than the American republic based on assimilation of immigrants to a common constitutional ideal. A genuine plea for an American republic, not an empire, is found in the late Walter Karp, The Politics of War (1979), and while it is scrupulous in its assertion of republican virtue and rejection of American empires abroad, it carries none of the ugly prejudices to which Buchanan is so attached and with which he so dismayingly tars the political project of American republicanism.

23 I briefly discuss these categories of international legal imperialism, US imperialism and anti-imperialism here in this Part 2. I raise them not in order to set them out fully or defend them in definitive terms, but merely to sketch the outline of a way of seeing the international world that is an alternative to the usual manner of international lawyers.

24 Noam Chomsky almost agrees: 'On the "nascent imperialism of international legalism and international institutions", I almost wish I could agree with you - and was pleased to be able to help define the framework that defines you as a moderate between the opposed lunatics. My own view is that it would be a better world, marginally, if international law and institutions could play some role independent of the manipulations of the great powers, influence varying roughly with power, as expected. But our world is very different'. Noam Chomsky, e-mail to Kenneth Anderson, 21 October 1999. See also N. Chomsky, The New Military Humanism: Lessons From Kosovo (1999). 
least partly as a competitive response of one form of imperialism against another, the 'really existing' hegemon against a potential rival. ${ }^{25}$

This is obviously a large and provocative thesis, and my purpose for raising it here is decidedly not to seek to 'prove' it. In some sense, such large 'views of the world' as either 'liberal internationalism' or 'imperialism' are never really provable as such. Instead one invites a reader, on the basis of a picture drawn out of the evidence, to recognize it as a plausible, or more plausible, description of the world, rather than as proof of it. The evidence is always interpretable in different ways, and 'plausibility' is a more honest goal than 'proof'. Be that as it may, this discussion will not even attempt to reach 'plausibility'; instead it aims simply to alert the reader that a radically different way of seeing international NGOs, international organizations, and states sympathetic to the ban campaign, on the one hand, and the US and its refusal to join the ban, on the other, is at least possible. Obviously I believe there is a great deal of 'plausibility' in the alternative, radical description of 'two competing imperialisms' .

But I do not necessarily believe that the imperialism thesis is fundamentally contradictory to the conventional liberal internationalism that is normally applied, by international public lawyers of a certain internationalist persuasion at least, to the landmines campaign. It seems to me, as a terminological matter — about which, again, I will not say more in this discussion - that it is possible to accept that such movements as the landmines ban campaign are genuinely examples of 'liberal internationalism' — at its best, no less - and yet simultaneously examples of ‘imperialisms'.

Both descriptions, liberal internationalism and 'competing imperialisms', are in some sense true, or at least 'plausible', in this matter of the landmines ban. Comprehending what is implied by each description is critically important, it seems to me, for understanding simultaneously what the activist course of action should be but also the limitations that should be considered precisely because the activism is not just liberalism, but also imperialism, in all its excess, hubris, imposition, and presumption of its own virtue. ${ }^{27}$ Liberalism, whether of the internationalist variety or any other, is often drunk with triumphalism and is rarely capable of seeing the damage it can

25 The view that the US is an imperialist, interested in preserving its dominance over other sources of power, and in particular supranational institutions of the UN system, is of course widespread, especially among the American left. See, e.g., Klare, 'The Clinton Doctrine', Nation, 19 April 1999, at 5 ('the NATO bombing is part of a larger strategic vision ... the United States has a vested interest in maintaining international stability ... it must be able to act on its own or in conjunction with its most trusted allies (meaning NATO)'); Editorial, 'Destroying Kosovo', Nation, 19 April 1999, at 3 ('the Administration once again degraded the UN's authority and marginalized Security Council members Russia and China').

26 I should acknowledge my debt to the 1999 Grotius Lecture by Nathaniel Berman, published as Berman, 'In the Wake of Empire’, 14 American University International Law Review (1999) 1521.

27 This methodology, of undertaking (mostly) liberal action while analysing from a radically sceptical position, in order to reach a synthesized form of action that could best be described as 'chastened liberalism' or 'liberalism as restrained by the virtue of modesty', is likely to strike many readers as exceedingly strange. Obviously it presupposes a problem of liberalism that goes far beyond liberal internationalism, in that it starts from the proposition that liberalism is a 'closed' and 'complete' philosophical system which has great difficulty accepting critiques that embody values that are not themselves valued by liberalism — the standard liberal-communitarian debates come to mind; see, from 
inflict; for that it needs to be seen from a genuinely radical, critical perspective. If I did not believe something like this, then I would not simultaneously spend the amount of time I do as an activist on the cause of banning landmines, while writing sharply critical articles such as this one which aim quite deliberately at radically reinterpreting actions including my own, as a kind of iconic reminder of hubris. ${ }^{28}$

Four elements (at least) of the method I have briefly sketched above are likely to strike the confirmed liberal internationalist as preposterous. The first is the proposition that liberal internationalism and the two competing imperialisms can both be 'true' as descriptions of the landmines ban campaign and the US response. Rather, says the liberal internationalist, they would appear to be disjunctive if not exhaustively disjunctive explanations, such that if you accept one you must reject the other. Be a liberal or be a radical, but do not believe you can commune in both churches at once.

The second is the suggestion that there is any utility in considering radical critiques of actions or campaigns or anything else that arise or, loosely speaking, 'derive' from liberal internationalism. Rather, says the liberal, liberal internationalism is 'complete' as a model of ethical international order, and no genuine understanding results from examining its actions from radical perspectives. The claim of liberal hubris is therefore simply misplaced, because there is no genuinely 'true' radical perspective from which to perceive this alleged hubris and it therefore cannot constitute hubris. There is no imperialism at least in the actions of the international NGOs, international organizations, and sympathetic states in support of the ban campaign (although the US actions are another matter); their actions are just plain old liberalism.

The third is the claim that there is anything to the idea of "two competing imperialisms'. Whatever limitations liberal internationalism may have, says the liberal, whatever 'modesty' it ought to exhibit in its claims to have an ethical plan of

the voluminous literature, J.B. Elshtain, Augustine and the Limits of Politics (1995). The presumption of completeness leads liberalism to a hubristic self-confidence in its actions and social prescriptions, and an unwillingness to see the possibility of, for example, dialectically bad consequences and social costs deriving from its social programme. The 'chastened' or 'modest' liberal, who understands the tendency to hubris inherent in liberalism, attempts to take radical critiques - which of course can vary hugely and be contradictory as between themselves - even incoherently into what might still remain, fundamentally, a liberal plan of action. I discuss the idea of liberalism's presumption of 'completeness' briefly in an essay on the late Christopher Lasch, in Anderson, 'Heartless World Revisited: Christopher Lasch's Parting Polemic Against the New Class', Times Literary Supplement (London), 22 September 1995; and in Anderson, 'Review Essay: A New Class of Lawyers: The Therapeutic as Rights Talk', 96 Columbia Law Review (1996) 1062, at 1081-1092. The idea is briefly applied with respect to liberal internationalism in Anderson, 'Illiberal Tolerance: An Essay on the Fall of Yugoslavia and the Rise of Multiculturalism in the United States', 33 Virginia Journal of International Law (1993) 385. I do not suppose that those who really are smitten with liberal internationalism will find this very persuasive, since they are not likely to see that there is even the risk of a problem of liberal immodesty.

28 As a method of social action and social criticism, I take at least some comfort from M. Walzer, The Company of Critics: Social Criticism and Political Commitment in the Twentieth Century (1988), which argues that something like the tension I suggest must be maintained between radical critique and suitably chastened liberal action; likewise, too, albeit in the much more dramatic circumstances of the French Resistance, the poetic notebook of Rene Char, Feuillet d'Hypnos (1946), especially the section 'France-of-the-caverns', dedicated (not unsurprisingly) to Albert Camus. 
international action, the claim of 'two competing imperialisms' as an alternative, radical vision of the landmines campaign and the US response to it is unpersuasive on its own. It is internally incoherent as a description, even accepting the possibility of an analysis based on imperialism.

The fourth arises from the third, and is the view denying that there could even be such a thing as 'international legal imperialism'. There is, to be sure, US imperialism; it is a fact of international life. But international law is the non-imperial alternative to US imperialism and hegemony, and it ought to be celebrated as such. ${ }^{29}$

This is not the place to undertake a response to each of these objections. I have raised the possibility of an alternative vision of how such apparently benign and virtuous things as the landmines campaign might be construed, the possibility of locating it and the US response within an framework of imperialism, because I think that my observations in the remainder of the discussion would be entirely (rather than merely mostly) puzzling to the international lawyers who are likely to be this article's readership without at least some sense of how far from liberal internationalism this critique resides. This may be taken by readers as simply another reason to dismiss it as pointless. To that I would ask that those readers who are part of the collegium of international law, and who tend to accept the standard 'master narrative' of liberal international law undertake, insofar as possible, in order to glean something from the subsequent discussion of international NGOs and the US response, to invoke some principle of intellectual charity at least while reading this.

Still, one last thing needs mentioning before proceeding onwards to an iconoclastic account of the international NGO movement and the campaign to ban landmines. Even among those exercising an admirable amount of intellectual charity in the course of reading this article may still wonder what could conceivably be meant by describing the enterprise of international law as I have described it, as international legal imperialism. A wide part of educated opinion in Europe, particularly in France, regards US actions on many matters as the exercise of illegitimate hegemony, which I

29 It also seems to me that however wild, even paranoid, the view might seem to some that the international legal order could be seen as 'imperialist', this pales beside the fantastically strong assertions by President Chirac, supra note 17, as to the totalizing nature of US imperialism, running all the way from military strength to financial dominance to linguistic and cultural hegemony. Chirac's vision — widely shared, so far as I can tell, among European intellectuals of all varieties - is one of a seemingly seamless web of US imperialism, which must be resisted even when, in the case of language and culture, it scarcely seems to be the 'programme' of the United States government that is causing a movement to globalism on American cultural terms but instead the liberal, autonomous choices of individuals worldwide. I am no friend of imperialism, whether US imperialism or any other, but once Chirac goes beyond those matters which are more or less within control of government policy, such as military deployments and, to a lesser extent, finance and capital, to such things as language and culture, then Chirac is confusing 'imperialism', as a theory and means of 'governing', with shifting tectonic plates of global culture; appealing to such concepts as imperialism and hegemony loses its bite, because analysis is no longer tied in any strict ways to the policies of a government but attributed, much less usefully, to America as such. It is too broad an attribution to mean very much, whereas denouncing the US missile attack on Sudan, for example, as the rash and unjustified act of an imperial and hegemonic aggressor seems to me both correct and meaningful. In any case, Chirac has the admirable honesty to inform us that the point of both the institutions of Europe and the institutions of the UN is to stand against the hegemony of the United States. 
take to be not unrelated to imperialism. ${ }^{30}$ But is international law not being invoked, by the Europeans in particular, as a means to resist, at least at the rhetorical level, American imperialism? How is it that it can be described as its own form of "competing imperialism? ? 31

But of course there is no reason why an empire cannot be founded on law and legalism, and there is likewise no reason that it cannot, according to both its own lights and some broader standard of moral judgement, be benevolent. ${ }^{32}$ What makes an empire an 'empire', and imperialism 'imperialism', is neither its legal formalism nor its benevolence, but its imposition from above and from without - geographically, culturally, politically and economically. ${ }^{33}$ Imperialism depends neither upon consent of the governed nor upon democratic assent for its assertion of political legitimacy; it can depend upon numerous other principles of legitimacy, ranging from economic necessity $^{34}$ to the 'white man's burden' to the promulgation of the faith. Most frequently invoked in today's world by those willing to call directly for an imperial order at the level of the United Nations, in the form of protectorates and mandates to govern in places of massive human rights abuse, the aftermath of war, or the so-called

30 See my earlier footnotes regarding President Chirac's 4 November 1999 speech laying out this view.

31 There is no need here to take a position on whether and to what degree imperialism 'must' be driven by economic, rather than political, factors - the classic 20th century debate largely between Marxists and liberal thinkers. I am happy to accept that imperialism often has no special relation to capital, let alone to Rudolf Hilferding's category of 'finance capital' (R. Hilferding, Finance Capital: A Study of the Latest Phase of Capitalist Development (orig. 1910), ed. T. Bottomore (1985)), and to accept Hans J. Morgenthau's decidedly non-Marxist, classically 'neutralist' definition of it as a 'policy that aims at the overthrow of the status quo, at a reversal of the power relations between two or more nations'. H.J. Morgenthau, Politics Among Nations: The Struggle for Power and Peace, 4th ed. (1966), at 42. Morgenthau's definition - in some sense a modern expression of Augustine's concept of animus dominandi (see Elshtain, supra note 27, at 93-94) - seems to capture the imperial essence of, for example, the Chirac project quite nicely; that it is an imperialism in opposition to another imperialism, US imperialism, seems neither here nor there. Of course, not all the visions of supranational institutions conform to Chirac's, but the assumption that they should take power and carry legitimacy in the world away from existing sovereign states, whether the United States or others, seems to me amply to fill Morgenthau's carefully non-ideological definition.

32 A standard undergraduate textbook on international relations, after all, deliberately associates 'imperialism' as being 'invoked proudly to imply what Britain had contributed toward civilizing the parts of the world once or still controlled by Britain - the rule of law, parliamentary institutions, a rational administration of civil servants with some sense of public responsibility (hitherto a rather rare phenomenon in many regions), and a conviction of the worth and rights of human beings'. J.E. Dougherty and R.L. Pfaltzgraff, Jr., Contending Theories of International Relations: A Comprehensive Survey, 3rd ed. (1990), at 227. All that, one might say, and still, unapologetically imperialist.

33 I take this to be in conformity with Morgenthau's standard definition, supra note 31.

34 This is the famous analysis promulgated by John A. Hobson (Imperialism: A Study (orig. 1902) (1965)), V.I. Lenin (Imperialism: The Highest Stage of Capitalism (1939)), and Rudolf Hilferding, supra note 31. As Lenin put it in the standard Marxist-Leninist view: 'Imperialism is capitalism in the stage of development in which the dominance of monopolies and finance capital has established itself; in which the export of capital has acquired pronounced importance; in which the division of the world among the international thrusts has begun; in which the division of all territories of the globe among the great capitalist powers has been completed', at 89 . 
'failed states', is that there is no other choice - a sort of negative invocation of the benevolence principle. ${ }^{35}$

There may genuinely be no choice in some of these cases. But consent of the governed is still lacking, democratic legitimacy in the long run is still lacking, and anyone who believes that those deficits do not produce their own pathologies over the long term - and frequently short term - would do well to review the history of a wide variety of contemporary benevolent protectorates, starting with Somalia and Haiti. ${ }^{36}$ Of still greater concern than the situations of genuine protectorates and failed states, however, is the broadly held perception, particularly among liberal internationalists, that if not the UN system in precisely its present form, then some form of emergent global order really does have legitimacy notwithstanding its notable - and in my view, insurmountable - democratic deficits. It has instead, apparently, the legitimacy of international law, and there is a certain sense of 'ships passing in the night' if one attempts to ask what, precisely, gives international law this legitimacy. ${ }^{37}$ We count democratic legitimacy to be the sin qua non of legitimacy of the sovereign national state, but why, I wonder, do we suddenly jettison it when it comes to the international system - for no better reason, so far as I can tell, than that it really cannot be achieved? ${ }^{38}$

35 Indeed, the rehabilitation of the very word 'imperialism' within at least First World countries and their liberal internationalist elites is a striking phenomenon. For an important historical analysis of the evolution of the term, see R. Koebner and H.D. Schmidt, Imperialism: The Story and Significance of a Political Word (1964). The journalist David Rieff, for example, is happy to describe himself as an imperialist, although he does not shy away from an understanding of the bad consequences that also arise from it.

36 A useful place to begin, notwithstanding that I disagree almost entirely with its conclusions and outlook, is M. Kaldor, New and Old Wars: Organized Violence in a Global Era (1998); she recognizes plainly, as Alex de Waal put it in an excellent review (Waal, 'We Do Deserts, We Don't Do Mountains', London Review of Books, 11 November 1999, at 17, 19), that in places like Bosnia and Kosovo, and by extension other places as well, 'international engagement ... is profound and will be long-lasting, and thus ... imperial-style responsibilities should be taken seriously'. See also J. Coulon, Soldiers of Diplomacy: The United Nations, Peacekeeping and the New World Order (1998); and Jonathan Moore (ed.), Hard Choices: Moral Dilemmas in Humanitarian Intervention (1998).

37 For many international lawyers, especially academics, there is a certain weariness in taking up this question, a certain desire to say, 'Haven't we long since settled this?' To which the appropriate response is, 'Well, yes, you settled this among yourselves to your international lawyerly satisfaction, imagining that no one else mattered to reaching this agreement, and now you seem surprised when the rest of us don't feel bound by the agreements and understandings you worked out within your hermetically closed circles.'

38 I take up this question in an aggressively polemical fashion in Anderson, 'Secular Eschatologies of the Internationalized New Class', in P. Juviler and C. Gustafson (eds), Religion and Human Rights: Competing Claims? (1998), at 107. The reliably sanctimonious Michael Ignatieff, reviewing the article in the New York Review of Books (Ignatieff, 'Human Rights: The Midlife Crisis', New York Review of Books, 20 May 1999), seemed to conclude that it was a question beneath answering, and offered platitudes that because the human rights movement stands with victims (as Human Rights Watch asserts as its motto), it cannot have democratic deficits. This does not seem to me to be a serious argument; it is, however, a confirmation that liberalism is a closed system that has the gravest difficulties hearing its critics or even acknowledging that there might be grounds of criticism. A genuinely thoughtful - sometimes sympathetic and sometimes critical — response is made by José Alvarez in his concluding remarks to the University of Michigan conference at which this paper was originally delivered; he notes, by way of criticism, that I have a tendency to romanticize democracy, especially within sovereign states, and to 
This assertion of the legitimacy and supremacy of international law over sovereign states does seem to me to fill the requirements of imperialism quite nicely. That it has not yet got very far in the teeth of US hegemony is neither here nor there; that it is opposed to, in my view, an equally illegitimate US imperialism does not seem to me to make it any less imperial in its pretensions. What it is about, what it aims for, what its adherents (including many readers of this article) fervently yearn for as idealists, people of good will, liberal internationalists, is the establishment of an international system that is genuinely constitutionally supreme with respect to both nation states and the people that, in the best of cases, they democratically represent. In no very radical sense, it seems to me the quintessence of empire. And it is in this sense, as a partisan of democratic legitimacy, that I call it 'international legal imperialism'.

\section{The Romance Between NGOs and International Organizations}

\section{A Seven Lessons from the Landmines Ban Campaign}

Although the history of the Ottawa Convention is still largely oral history, one indispensable written source has emerged, To Walk Without Fear: The Global Movement to Ban Landmines. ${ }^{39}$ Edited by two Canadian academics, Maxwell A. Cameron and Brian W. Tomlin, and a Canadian diplomat extremely active in the international campaign, Robert J. Lawson, its collected papers, drawn from a range of NGO activists, academics, and others, are the first serious effort to record the history of the landmines ban campaign and assess its impact upon the rest of international law and lawmaking. Drawing from this book and my own experience, a series of observations about the ban campaign stand out.

First, the international campaign to ban landmines began entirely — one hesitates to use so strong a word, but in this case it is applicable - as an effort of international NGOs. ${ }^{40}$ The initial steps began with the International Committee of the Red Cross (ICRC); its surgeon staff particularly, alarmed at the sharp increase during the 1980s in the number of landmine victim limb amputations, persuaded the ICRC to raise the issue in its diplomatic, legal and public awareness efforts. ${ }^{41}$ The ICRC would be the first

genuflect before it even where, under other circumstances - viz., where I did not need it as a category to stand against the evils of supranational imperialism - I might have doubted that it had very much 'democratic' legitimacy at all. (Alvarez, 'Multilateralism and its Discontents', 2 EJIL (2000) forthcoming.) I acknowledge that Alvarez has identified a matter of serious concern in my own analysis; I do not think it is fatal to the analysis, but it is serious indeed.

39 M.A. Cameron, R.J. Lawson, and B.W. Tomlin (eds), To Walk Without Fear: The Global Movement to Ban Landmines (1998).

40 In this account of the background history of the campaign, I draw heavily from my own experience, but also from the very important historical account given in Williams and Goose, 'The International Campaign to Ban Landmines', in ibid. at 20.

41 See ICRC, Landmines Ban Brochure (1992). 
to admit that its nascent campaign had comparatively minimal visibility until a coalition of international NGOs with concerns about landmines arising from very different standpoints, came together to initiate what later became known as the International Campaign to Ban Landmines (ICBL). ${ }^{42}$ The initial groups, which had met in various ways and combinations in the run up to the formal launch of the international campaign at a meeting at the offices of Human Rights Watch in New York in 1992, were Handicap International (France), Human Rights Watch (US), Medico International (Germany), Mines Awareness Group (UK), Physicians for Human Rights (US), and Vietnam Veterans of America Foundation (US), which became the first ICBL steering committee. ${ }^{43}$

The ICBL expanded over the next few years to number more than 1,200 NGOs in some 60 countries; ${ }^{44}$ although the ICRC, for reasons of its mandate, did not formally join the ICBL coalition, it and national Red Cross and Red Crescent societies and their federation fully supported the process leading up to the Ottawa Convention. ${ }^{45}$ It was a striking part of the campaign that diverse NGOs could find bases on which to support the ban campaign drawing upon their own organizational mandates. Thus, for example, Human Rights Watch and the ICRC regarded landmines as a human rights and humanitarian law issue, while such groups as Medico International, Physicians for Human Rights, or Handicap International saw it as a medical and public health issue, while still others, such as the Vietnam Veterans of America Foundation saw it as a matter of dealing with the consequences of war in a social and developmental sense.

Second, governments were initially entirely uninterested; it was regarded by governments everywhere as pie-in-the-sky, even if they were not actively hostile to the idea. Governments regarded the only real possibility as being a strengthening of the existing Landmines Protocol, so-called Protocol II to the Convention on Conventional Weapons; ${ }^{46}$ the ICBL had long since concluded that amendments to Protocol II, governing the rules for the 'proper' use of landmines, were useless. ${ }^{47}$ At the same time, while governments were generally unpersuaded as to the idea of a

42 Cognescenti of the history of ban campaign will see that I am here deliberately stepping aside from some unproductive debates over which NGOs 'really started' the ban campaign; together with some ugly squabbles over the 1997 Nobel Prize awarded jointly to the long-time coordinator of the ICBL, Jody Williams, and to the ICBL itself, these arguments have wasted considerable time - although perhaps they are inevitable in a campaign organized deliberately on a loose and ad hoc basis in order to have maximum flexibility of action. With some trepidation, as many of the parties involved have vehemently disagreed with the article, see T. Marshall, 'Nobel Prize Sets Off a Landmine', Los Angeles Times, 6 February 1998, at 1.

43 This meeting is described at Williams and Goose, supra note 40, at 22.

44 Ibid.

45 See generally Maslen, 'The Role of the International Committee of the Red Cross', in To Walk Without Fear, supra note 39 , at 80 . One influential sector of the international NGO community which never really joined the coalition - somewhat surprisingly, to my mind — was international environmentalism, for example such organizations as Greenpeace; these groups never really decided to see the litter of landmines as, for example, a form of 'pollution' or some other form of attack upon the environment.

46 Protocol on Prohibitions or Restrictions on the Use of Mines, Booby Traps and other Devices, UNGA Doc A/Conf. 95/15 and Corr. 1-5; 19 I.L.M. 1534 (1980).

47 Human Rights Watch/Physicians for Human Rights, Landmines: A Deadly Legacy (1993), at 261-306. 
universal, comprehensive ban treaty, some sympathetic governments and legislatures, at the instigation of local NGOs affiliated with the ICBL, began to pass unilateral restrictions of their own on landmines, including restrictions on institutions and companies under their jurisdiction, ranging from prohibitions on use by their own militaries to export bans directed against arms manufacturers. ${ }^{48}$

Third, the ban campaign had a simple, easily understood message - a complete and comprehensive ban, nothing more, nothing less. The message was so simple that it could fit whole into an advertisement or public awareness message. I was once asked, for example, to provide the text of a model landmines ban treaty for the ICBL; after due consideration, the text read in full:

States parties to this Convention undertake never under any circumstances to produce, stockpile, transfer, or use antipersonnel landmines, and further undertake within a five year period upon ratification of this Convention to destroy all existing stockpiles of antipersonnel landmines. ${ }^{49}$

Although the final Ottawa Convention is of course longer and more detailed, in contrast to other arms control or humanitarian law treaties it preserves the spirit of transparent language and clear, uncompromising and unambiguous undertakings. This utter moral and political clarity was an integral part of the campaign in reaching various publics.

Fourth, although the possibility of banning landmines was seen strongly as a threat — if not complete nonsense, at the outset - to the world's militaries, it did not represent an overwhelming economic threat to arms makers. Anti-personnel landmines represented then, and more so now, a very modest part of the munitions sector of arms manufacturers. ${ }^{50}$ Giving up mines manufacture did not represent a significant blow to the profitability of diversified defence contractors. ${ }^{51}$ As a

48 These early efforts are catalogued in Human Rights Watch/Physicians for Human Rights, Landmines: A Deadly Legacy (1993). Nearly all these efforts drew on the example of a US senator, Patrick Leahy, who, together with Congressman Lane Evans, had been pursuing the matter legislatively in the United States almost singlehandedly - and with striking success even before the ICBL existed, having produced unilateral US moratoria on landmines' export over several years prior to the creation of the ICBL. Ironically, part of the success of Leahy and Evans' efforts lay in the very invisibility of the effort; the US military did not feel especially threatened by these efforts, and certainly favoured strengthening prohibitions on the 'proper' use of mines, until ban efforts crystallized and went public in the form of the comprehensive ban treaty. But it was an important part of the development of the campaign that ban advocates in a wide range of Nato countries were able to say to their legislatures and militaries, 'if the United States can ban mine exports, then surely we can too'.

49 Author's files, 1993.

50 See International Campaign to Ban Landmines, Landmine Monitor Report 1999: Toward a Mine-free World (1999), at 5-12, for the best current survey of the production and stockpiling of landmines. This is true for arms manufacturers in the aggregate notwithstanding the bankruptcy of a major Western producer of mines - the Italian Valsella company. See 13 Jane's Defence Weekly (1997) 11, 1 October.

51 For a time in 1993, George Soros, the financier and philanthropist, happened to hold the third largest share stake in Alliant Tech Systems, an American munitions manufacturer that produces landmines for the US military. On account of that connection, I was able to hold discussions with certain senior corporate officers at Alliant Tech, who told me informally that landmines were not a major part of Alliant's line of corporate products or corporate profits. 
consequence, no industrial or private sector groups had a strong incentive within the Nato countries to contribute money to a counter-campaign. The opposition to the treaty was entirely a matter of governmental policy, making that policy considerably more susceptible to public pressure by NGOs. Militaries might be opposed to the ban, but the military-industrial complex, so to speak, was not engaged on the issue.

Fifth, the treaty process represented a new approach to international lawmaking because - largely in response to international NGO pressures - once a core of influential governments had endorsed the ban treaty, the negotiating principle was not the usual method of arms control treaty negotiation on the principle of obtaining consensus on each point along the way, no matter how much the treaty had to be watered down or how long it took. ${ }^{52}$ Instead, again on account of international NGO pressures, sympathetic governments adopted a new principle of negotiating a treaty among 'like-minded' states — in effect, accepting the comprehensiveness of the international NGO position and its refusal to compromise the essentials of the landmines ban. The wager, of course, of negotiating a treaty among the like-minded alone (even though the club of the like-minded has eventually grown to include numerically the vast majority of states) was (and is) that the treaty will eventually gain adherence even from those who were not in the beginning like-minded. ${ }^{53}$

Sixth, governments eventually began to come on board the landmines ban cause for three principal reasons. NGO pressure, first, brought them to an awareness of the genuine extent of the problem and put it on their policy agendas. Many governments recognized, second, that for them the decision to ban landmines was essentially cost and risk-free; it was unlikely if not unthinkable that they would fight any wars, let alone wars requiring mines. In any case, many of the European states favouring the ban knew (as members of Nato which had, the alliance notwithstanding, decisively disarmed themselves during the course of the 1990s) that should the unlikely moment of war appear, the United States would fight it, as occurred in Kosovo, because only the US would have the weapons and troops. ${ }^{54}$ Finally, numbers of the medium-sized powers, including the Nordic countries and such lesser Nato powers as Canada, came to see the campaign to ban landmines as an important counterweight to the political hegemony of the United States; they perceived an alliance with international NGOs as providing ideological pressure against not only America's material advantages as the world's superpower, but against its assertion of moral and political legitimacy in setting the terms of such things as the use of landmines not

52 This can be contrasted with the usual approach of disarmament treaties such as the Chemical Weapons Convention or the Biological Weapons Convention, each of which was many years in negotiations and discussions.

53 As of this writing, 11 November 1999, the Ottawa Convention has garnered 136 signatories and accessions, and 89 ratifications. A convenient, if unofficial, way of checking on signature and ratifications is to consult www.mines.gc.ca

54 See John R. Bolton, Senior Vice President, American Enterprise Institute, Testimony Before the House International Relations European Defense Subcommittee, 12 November 1999, for a useful discussion of the US, Nato and Europe on defence issues. 
around the brutal facts of Angola and Cambodia, but instead around the US military's war-fighting doctrines in the Korean peninsula. ${ }^{55}$ Resentment of US hegemony should not be overlooked as at least a residual reason for participation in the campaign. As the editors of To Walk Without Fear expressed it, ' ... small and medium-sized states can, in partnership with global civil society, overcome great power opposition; the US does not always have to lead in the new post-Cold War environment. ${ }^{, 56}$

Seventh, and the most far-reaching in its implications, the ban campaign by its end stages was conceived by sympathetic governments, United Nations institutions, and the international NGO movement as being a genuine partnership between NGOs, international organizations and sympathetic states - between, so to speak, public and private. The 'Ottawa process', so called — the diplomatic and international NGO processes leading up to the December 1997 treaty-signing ceremonies in Ottawa reflected a decision by the Canadian government, among others, to put very significant resources and prestige behind the ban campaign. ${ }^{57}$ The famous press conference held at the end of the critical December 1996 Ottawa planning meeting, including parallel meetings of NGOs and states, at which the Canadian foreign minister, Lloyd Axworthy, made the surprise, radical announcement that Canada would hold a treaty signing ceremony a mere year later, electrified the activist world. But it also, to a remarkable extent, electrified the sympathetic diplomatic and international organization worlds as well - and, not insignificantly, infuriated the American delegation, which had not been warned in advance, although the NGO activists had been notified to orchestrate a 'spontaneous' standing ovation. ${ }^{58}$ Yet that event was preceded by numerous smaller, regional conferences designed to build support for the treaty; in these conferences the model was the same partnership of

55 See the earlier references to Chirac's 4 November 1999 speech and accompanying discussion.

56 Cameron et al., supra note 39, at 13. To assert that the landmines campaign has 'overcome' great power opposition is, however, surely illusory; more accurate would be to say that it has ignored the failure of the United States, Russia, China, India, Pakistan, Israel, and others to join the Ottawa Convention. Whether the wager that the like-minded states can persuade the unlike-minded to join at some point is a wager and one which I have always favoured taking — but it is wishful thinking, the effect of focusing on the formality of the Ottawa Convention, a mere piece of paper, rather than on the goal it merely serves, to ban landmines, to speak of overcoming that which has as yet barely been confronted. The Ottawa Convention is a great achievement, but it is, frankly, the childishness of small and weak states to think that tweaking the noses of the great powers by signing a treaty opposed by those powers means 'overcoming' them.

57 See Tomlin, 'On a Fast Track to a Ban: The Canadian Policy Process', in To Walk Without Fear, supra note 39, at 185 . It needs to be understood that the so-called Ottawa Process was a term coined by diplomats to describe the events between the planning meeting in Ottawa in December 1996, when Canada publicly committed itself to signing a ban treaty a year later, and the treaty signing in Ottawa in December 1997, including several preparatory drafting sessions, the most important of which took place in Oslo in September 1997. It was a critical period for the campaign; however, the international campaign had been underway since 1992, long before the Ottawa Process existed.

58 For a description of the event, see Cameron, 'Democratization of Foreign Policy: The Ottawa Process as a Model', in To Walk Without Fear, supra note 39, at 438; see generally Tomlin, 'On a Fast Track to a Ban: The Canadian Policy Process', in To Walk Without Fear, supra note 39, at 185. 
states and NGOs, holding meetings in parallel in such places as Mozambique and Cambodia. In effect, international NGOs and the core ban states had decided that they had much to gain in pursuit of the common goal of a ban by leveraging off one another.

\section{B The Partnership Between 'International Civil Society', Sympathetic States, and International Organizations}

This partnership between international NGOs, on the one hand, and sympathetic states and international organizations, on the other, bears closer examination, because it is regarded as a principal, if indeed not the principal, legacy of the landmines campaign, and the central element in the new template envisioned for international law-making. ${ }^{59}$ Most of the writers in To Walk Without Fear hail this belief fervently, and it is today widely and equally fervently hailed by the international activist community, as well as by the policy makers of sympathetic governments and international organizations. The ban campaign and its forging of a partnership between international public institutions, including sympathetic states, and international civil society, so-called, is the model of a new and better way of creating international law. As Canadian Foreign Minister Axworthy put it:

The need for new partnerships to address global problems and the increased power wielded by a wide range of state and non-state actors intersected in the landmines campaign ... it brought together a mixed group of players into a coalition without precedent... The landmines campaign was the harbinger of the new multilateralism: new alliances among states, new partnerships with non-state actors, and new approaches to international governance. ${ }^{60}$

And indeed, several international campaigns are now underway drawn largely from this model - the Rome Statute process toward the ICC, the campaign spearheaded by the ICRC and Human Rights Watch to ban blinding laser weapons,

59 This extends even to a disturbing trend, which is the growing dependence of the international NGO campaign on funding from sympathetic states, such as Canada, to continue the vital post-Ottawa Convention work of monitoring compliance with the treaty. Until recently, and certainly in terms of overall dollars contributed, the only non-state funder of the Landmine Monitor — envisioned as the primary report annually monitoring treaty compliance — has been the Open Society Institute Landmine Project, which has given several hundred thousand dollars in support of Landmine Monitor directly and to Human Rights Watch to support that work. But the Open Society Institute Landmine Project — I am a member of its advisory board, which makes decisions regarding funding from its approximately $\$ 1$ million a year - is gradually going out of business, and it is possible that no other private donors will step in to take its place, at least not in significant amounts. The picture that this paints is quite a different one from international NGOs working in 'partnership' with sympathetic states and international organizations; instead, it paints the disturbing possibility of international NGOs working as grantees and subcontractors for states from whom they receive all their funding. Over time this would likely severely hamper the independence of the international NGOs and be a most unfortunate outcome. See Economist (US edition), NGOs: Sins of the Secular Missionaries, 29 January 2000, at 25-27.

60 Axworthy, 'Towards a New Multilateralism', in To Walk Without Fear, supra note 39, at 452-453. 
and the rapidly growing campaign against the use of child soldiers, among prominent examples. ${ }^{61}$ As Kenneth Roth, executive director of Human Rights Watch, has put it:

The landmines campaign ... can be seen as a model of what is to come ... already the focus has shifted forward, with NGOs looking to build similar partnerships with small and medium-sized governments on other causes. ${ }^{62}$

The template has certain key assumptions, however, few of which have been critically examined.

The central assumption underlying the idea that the landmines campaign is a new and better way of doing international lawmaking is that international NGOs are somehow 'international civil society'. The conceptual essence of this phrase is that international NGOs are somehow the international equivalent of what, within a single society, social and political theorists have long called 'civil society'. ${ }^{63}$ If that is so, then international NGOs are a species of 'intermediate' institution - neither state nor international organization, yet neither market nor private business enterprise. They are instead the so-called 'Third Sector' — voluntary civic and citizens' organizations, the international equivalent, apparently, of domestic society's churches, civil liberties organizations, service clubs, literacy volunteers, and all the structures of volunteerism that are so celebrated in Western democracies nowadays. ${ }^{64}$ As a consequence, according to the editors of To Walk Without Fear:

61 See post-conference notes to the Conference on Child Soldiers, Washington College of Law, American University, Washington DC, April 1998. The model for organizing is nearly the same in each case, and indeed the international NGO actors and staff are often the same; e.g. Human Rights Watch has taken a lead role in each, and Stuart Maslen, who worked for Unicef on landmines, has become the coordinator of the international NGO child soldier campaign. See also, for a critical commentary on the child soldiers campaign, Ralph Peters, 'Sometimes It Takes a Child to Raze a Village', Wall Street Journal, 1 February 2000, opinion page.

62 Roth, 'New Minefields for NGOs: After the War on Landmines, These Organizations Started New Campaigns', Nation, 13 April 1998, at 22.

63 For an exceedingly uncritical, indeed celebratory statement of the new 'international civil society' ideology, see Shaw, 'Civil Society and Global Politics: Beyond a Social Movements Approach', 3 Millennium: Journal of International Studies (1994) 650.

64 Scholarly literature on the concept of 'civil society' fills libraries; it is highly contested terrain, as a political, historical, and sociological matter. Rather than enter that (important) debate here, I will simply refer the reader to three general source books and their accompanying bibliographies: J.A. Hall (ed.) Civil Society: Theory, History, Comparison (1995); J.L. Cohen and A. Arato, Civil Society and Political Theory (1992); and John Keane (ed.) Civil Society and the State (1988). The international activists, bureaucrats, and diplomats who so freely use the term these days have in mind one central idea in an otherwise largely uninformed use of the term: they mean organizations which are neither private business enterprise nor organizations of the state or international public institutions - NGOs, in other words. It perhaps bears noting, at least, that this is not how Adam Ferguson, Adam Smith, Hobbes, Locke, Hegel or Marx would have understood the term; perhaps de Tocqueville would have, but perhaps not. See e.g. M.B. Becker, The Emergence of Civil Society in the Eighteenth Century: A Privileged Moment in the History of England, Scotland, and France (1994). Does its pedigree matter, when its users seem generally too ignorant of its origins to have adopted it from any specific historical tradition? Possibly not, but on the other hand it may say something about the shallowness of the liberalism endorsed by default, as it were, by partisans of liberal internationalism - a liberalism without roots deeper than the past several decades, bearing the many flaws of a specifically American rights-based liberalism, of the kind criticized by John Gray in Gray, Enlightenment's Wake: Politics and Culture at the Close of the Modern Age (1995) and especially his essay in 
Governments working together with global civil society can achieve diplomatic results far beyond what might have been possible in the Cold War era... The emergence of global civil society holds the promise of making existing international institutions more democratic, transforming them through innovation and experimentation, and anchoring them in world opinion. $^{65}$

International NGOs, because they are 'international civil society', are therefore a force for democratizing international relations and international institutions and, moreover, the authoritative bearers of 'world opinion'. They are therefore the legitimate representatives in the international sphere of 'people' in the world, in a way in which their states, even democratic states, and their state representatives, are not. International NGOs therefore have authenticity, legitimacy and authority of the 'people' of the world in a way that states and international organizations do not, and therefore ought to have a seat at the table of power. As Foreign Minister Axworthy put it in an address to NGOs in the midst of the Ottawa process:

One can no longer relegate NGOs to simple advisory or advocacy roles in this process. They are now part of the way decisions have to be made. They have been the voice saying that government belongs to the people, and must respond to the people's hopes, demands and ideals. ${ }^{66}$

Thus, international NGOs are 'international civil society', international civil society is the voice of the people of the globe, the voice of 'world opinion', and so states and international organizations must make a place for these NGOs at the negotiating tables, in the halls of power, because if they do not, these states - even, once again, democratic ones - and international institutions risk illegitimacy. Or as Maxwell A. Cameron puts it:

The Ottawa Process democratized foreign policy within the framework of existing representative institutions by using a partnership with civil society to expose policy to the test of publicity... The public diplomacy practised in the Ottawa Process compelled policy-makers to provide public reasons for their actions and exposed them to criticism from civil society by bringing an NGO coalition into the policy process, both as domestic partners and international allies. $^{67}$

the Times Literary Supplement (London) 28 April 195, at 28:

'... Americocentric liberalism has little, if any, salience in other parts of the world where the poltical agenda is governed not by individualist conceptions of law and rights but by the need to work out terms of peaceful coexistence among different communities'.

65 Cameron et al., supra note 39, at p. 13.

66 Axworthy, 'Notes for an Address by the Honourable Lloyd Axworthy, Minister of Foreign Affairs, to the Oslo NGO Forum on Banning Anti-Personnel Landmines', DFAIT (Canada) Statement, Oslo, 10 September 1997.

67 Cameron, supra note 58, at 441-443. One important weakness in much of To Walk Without Fear, including Cameron's, is that, being a Canadian book, funded partly by the Canadian government, and having largely Canadian contributors, its articles very often fail to distinguish between the actions and, indeed, legitimacy of civil society within Canada and those of international NGOs acting in the world at large. It is a measure of just how unreflective is the extension of civil society by metaphor from particular societies to the planet at large that these contributors, including Cameron, fail even to discuss the possibility that the authenticity of the public voice brought by institutions of civil society within Canada upon the Canadian government simply has no correlate in the international world, because all the world is not a 'society'. 
The seriousness with which states took the view that the NGOs were both the voice of world opinion as well as necessarily their partners was reflected in the number of state delegations which had even appointed staff of international NGOs as members to their delegations. In some cases that meant that some countries essentially handed their policy and negotiating apparatus to activists; in other cases, the government had its own line, usually sympathetic but not identical to the NGO position, but allowed the NGO inside access to the negotiations. And the Oslo drafting sessions, which developed the draft treaty itself, allowed not only the ICRC access in its traditional observer role - with rights of intervention and to be heard - but granted the same to the ICBL. And why not, since the negotiations took place not under the aegis of the United Nations or some other agglomeration of all states, but instead merely as a group of like-minded countries that could set any rules of participation they liked. It is an approach that has gained momentum in other spheres, including the process of negotiating the Rome Statute; the moment of 'international civil society' has apparently come, at least within the imperium of international legalism.

\section{But Who Elected the International NGOs? ${ }^{68}$}

Perhaps the point at which to commence a critique of this apparent victory of democracy through international civil society is to ask why international bureaucrats, for example, those who work for international organizations, have become so eager in recent years to embrace the language of international civil society? One can scarcely attend a meeting of international elites of one kind or another at which an international civil servant speaks these days without hearing, no matter what the topic, a sort of adulatorio to NGOs, a hymn of thanksgiving for 'international civil society' and how it is making international bureaucracy more accountable and effective. As one who has always worked from the NGO side of all things international, I can report what we all know, that it was not always this way. Why this shift? And why now?

It would be pleasant to think that the reason is that international bureaucracy has woken up to the fact of the effectiveness of the international NGO sector; it has come round to understand that public international organizations, like governments, are not very effective at the rapid and efficient provision of broad ranges of services. The dawning of a genuine humility - and not merely passivity — of international organizations, and a concomitant willingness to work with partners who may or may not have the credentials of states, may not be international civil servants or diplomats or anything else official, and certainly do not have the pension plans of international civil servants - well, this would all be to the good. And no doubt this is part of the explanation, especially in the changes of hearts and minds of many in international

68 This entire section, including the title, owes a great deal to David Rieff, both conversations over many years and to his recent essay, David Rieff, 'The Precarious Triumph of Human Rights', New York Times Magazine, 8 August 1999, Section 6, at 36. This is not to suggest, however, that he agrees with all of it; Rieff, to start with, is an unapologetic imperialist. 
bureaucracies to understand that international NGOs are not, per se, their enemy or, worse, simply irrelevant. No one believes they are irrelevant any more.

Still, it seems to me unlikely that this is the whole explanation. For one thing, this praise is nearly always, in my experience, offered within the very specific ideological language of 'civil society'. It is not merely pragmatic praise for non-governmental agencies and their performance; it is praise of a theory of politics framed within the terms of a discourse of politics, taken more or less directly out of the theoretical literature of 'social movements' and 'civil society'. ${ }^{69}$ It is scarcely necessary to adopt so wholeheartedly the whole theoretical apparatus of the Third Sector, the 'independent sector', a theory that is fundamentally about the democratic legitimacy of international NGOs, merely in order to praise their good works. But adopt it the international bureaucracy has.

And an important reason why the bureaucracy has adopted this theory of politics, of the legitimacy of the independent international NGO sector - long less resisted than ignored, treated as gadflies and irritants - is that public international organizations themselves are in desperate need of legitimacy. That is what they look to international NGOs to provide for them. But of course, this is to ask, why a crisis of legitimacy for public international organizations now, let alone the further question of how it is that international NGOs can help provide them legitimacy? The simplest answer, it appears, is that with the end of the Cold War, with the unfolding of globalization - including the formation of international elites across sectors of international business, international organizations and international NGOs - and the consequent raising of expectations within those loose international elites about the objectives, abilities, and responsibilities of international organizations, international organizations have volunteered and been volunteered for a variety of tasks that, in a word, require forms of legitimacy that international organizations have never had.

By 'legitimacy' in this context I mean merely that institutions act and be understood to act with authority that is accepted as proper and moral and just - 'right authority', to use the language of Augustine and Aquinas. ${ }^{70} \mathrm{I}$ do not impute to it here any special theoretical connotations; I am not locating it within the several contemporary theories of legitimation, such as Habermas's. ${ }^{71}$ I mean it in its most ordinary sense. The only particular requirement I will adopt here is that legitimacy in today's world requires that it be perceived to be legitimate by those over whom authority is exercised. In other times and places it might have been enough that one was the king, ordained of God, and perceptions of the peasantry be damned, but I take it we are beyond the

69 I have already given some references to the background literature on civil society; with reference to the equally voluminous literature on 'social movements', see S.M. Lyman (ed.), Social Movements: Critiques, Concepts, Case Studies (1995), and also the numerous articles in the social theory journal Telos throughout the 1980s.

70 The classical terminology, that is, of the criteria of the just war.

71 J. Habermas, Legitimation Crisis, trans. McCarthy (1975). 
point at which legitimacy can be separated, for very long, anyway, from its perception; we call this apperception 'democracy' and the consent of the governed. ${ }^{72}$

Given that this article is addressed to a readership of international lawyers and international law professors, I believe I am safe in assuming that my readers fundamentally believe that international organizations, and their underlying concept of 'world government' - what is today taken as the vision of Grotius ${ }^{73}$ - are legitimate, and deserve to be understood as the world's constitutionally supreme sources of authority and the exercise of power. At a minimum, I think it safe to assume that my readers believe that, in an 'objective' sense, the rule of 'right reason' international order — ought to govern the world - with wisdom, of course, and properly conforming to the rule of subsidiarity, and deference in all matters not of vital concern to local authority, and humility as to what can reasonably be dictated to the periphery from the centre, and so on. But international, finally and supremely.

My experience of international public lawyers is that they believe this so thoroughly that it is risking something like anathema to ask them for a defence of the legitimacy of what is not quite 'internationalism' (which, after all, can mean multilateralism among genuinely sovereign states), but is instead, as this article has used it, 'supranationalism' in all its glory. ${ }^{74}$ Public international lawyers tend to form a church of those converted to belief in supranationalism, and it thus seems to them it seems to you - deeply pernicious to ask for a proof, in effect, of what in this church constitutes the doctrine of transubstantiation and the immaculate conception. I have already suggested that this conviction on the part of public international lawyers is a belief in empire, ${ }^{75}$ the empire of international legalism, and it is a belief that for many of you - perhaps most or nearly all of you — is fundamentally religious and mystical in nature. You can scarcely imagine it otherwise.

For those for whom the virtue of this empire is a dogma beyond question, an article of faith, the only question of legitimacy is thus my requirement - we might call it the 'democracy requirement' - that legitimacy is inseparable, in today's world, from its perception by those under authority. But because you cannot imagine that supranationalism is truly illegitimate, the question of achieving legitimacy in the 'perception' sense is simply a matter of management of the masses to create this perception of legitimacy. Because the brutal fact remains that international organizations as they exist today do not have the perception of legitimacy to carry out the functions that international elites would assign to them, respect for legitimacy either

72 This discussion finally returns, in other words, to the methodological discussion of Part 2.

73 I say 'today' because I am not so certain that Grotius would have conceived of it in those terms, but I will not pursue that here.

74 I was, however, extremely pleasantly surprised at how civilly and courteously my admittedly heterodox views were received by attendees at the conference at which this paper was first presented, at the University of Michigan, September 1999. It was clear that these remarks were somewhat shocking to several of the conferees, but although my views were vigorously disputed, it was done in a spirit of courteous debate that I greatly appreciated. I learned a great deal from it and I hope that others learned from me.

75 See Part 2 of this article. 
from the planet at large or from the specific populations who would be directly under their governance. ${ }^{76}$

True, some populations have genuinely jettisoned the idea of national identity or else submerged it into something else, into Europe if not the world. What does it mean to be Dutch, for example, except to be European? What does it mean to be Canadian (at least in the eyes of the Canadian government, to judge by its efforts to control and purify its culture through broadcast and Canadian culture-content rules), except not to be American? There are many more populations, to be sure, that have embraced the ideal of an empire of international legalism in order to pursue the dream of ethnic, religious or national identity under the aegis of the emperor.

I once had a conversation, not long before the Yugoslav Wars broke out, with a Croatian nationalist who was simultaneously a genuinely liberal humanist. ${ }^{77}$ For him the crucial task was to take Croatia inside the then-European Community, and he wanted to be certain that the EC would be responsible for currency, central banking, fiscal policy and defence. Surprised, I asked him why he wanted that empire to take over what I would have regarded as the quintessential functions of the modern state, the sine qua non of sovereignty; the answer was that all those were secondary and a distraction from the main issue, which was the control of national culture. What he insisted upon keeping under state control, in the name of 'Croatianism', were the radio, television and the schools. The empire of the EC was to provide the guarantee of nationalism and conditions for the purity of Croatian culture.

Notwithstanding those populations that have made their peace with supranational empire, whether by seeing it as a thing into which to submerge oneself or as a space in which to establish an identity as against presumed cultural enemies closer to home, ${ }^{78}$ the world system of international organizations inevitably has a huge 'democracy deficit'. It is perceived, both by the world and by its servants, to have a democracy deficit because democratic legitimacy is precisely what it lacks. No one would seriously dispute this, I think, not even the most hardened supranationalist. In my view - I will not argue for this claim here, but simply declare it — the democratic deficit cannot be overcome by any organization that proposes to organize at the level of the whole

76 As de Waal, supra note 36, at 19, expresses it with respect to Bosnia and Nato - but the lesson is similar elsewhere and with respect to UN operations - 'Ultimately, Nato's role in Bosnia is underwritten, not by the mandate to hand over to newly developing Bosnian political institutions, but by its ability to threaten overwhelming force'. One might also recommend the account of the downing of the US helicopter that precipitated the US military withdrawal from Mogadishu, M. Bowden, Black Hawk Down: A Story of Modern War (1999), for a ground-up account of the difficulties of outside imperial forces in gaining legitimacy even through the barrel of a gun; for an account of the intervention and aftermath in Haiti, see B. Sacochis, The Immaculate Invasion (1999). The result is a tragic confusion of the roles of 'police' and 'military', with the possibility of large loss of life; for a discussion specifically of the differences in those roles and how the attitudes of international elites confuse them, see Anderson, 'Shame and the Honor of Soldiers', Panel on Law and Literature, American Society of International Law, April 1997, published in ASIL Proceedings.

77 Author conversation, Zagreb, Croatia, 1991.

78 This is essentially the argument that George Konrad, the Hungarian intellectual and novelist, made for how the Western democracies erred in fostering the Yugoslavia breakup. See Konrad, 'Nationalism Unleashed', Nation, 3 May 1999, at 4. 
planet. I likewise doubt it can be overcome even within the physically, culturally, and economically much smaller and much more homogenous European Union. Size and the number of people governed ultimately matter, and the limits of what can genuinely be called a 'democratic' political order are smaller than that which is economically efficient to contain within the regime of a genuinely global common market. The limits of democratic polity and the size of the economically efficient common market are not necessarily coextensive.

But if that is so, and democracy cannot be had for the planet as a whole 'thing', but only in its particular parts - one hopes, of course, in each and every one of them this does not change the fact that the legitimacy necessary to exercise power, and the necessary perception of that legitimacy, are obtained in this world only on the basis of democracy. The spread of democratic ideology worldwide is a great achievement, but unfortunately for the legitimacy of international organizations also a great inconvenience. It is inconvenient because such legitimacy as they have - at least their legitimacy to carry out the ever-stronger functions that globalizing elites ${ }^{79}$, whether in governments, international organizations, much transnational business, and of course international NGOs, would like them to carry out, such as keeping the peace, managing the world economy, trying war criminals, and so on - has not hitherto been based upon democratic assent. Yet now it is urgently needed, and where to get it?

The answer, unsurprisingly, is to turn to the only part of the so-called international community - i.e., international elites - that appears to have a connection with 'people': international NGOs. The sudden obsequiousness of international organizations toward international NGOs can be simply explained that in the absence of being able to look to actual populations of actual people, because that is at least unlikely and perhaps, if I am right, impossible, then international NGOs are asked to stand in for the 'people'. International organizations claim to have overcome the democratic deficit as an impediment to their legitimacy by having as their partners, and having the moral and political approval of, international NGOs, the voice of 'world opinion', and the loud and incessant invocation of 'international civil society' ${ }^{80}$ If the issue is effectiveness in affairs around the world, then the tone of international civil servants need be nothing more than pragmatic and specific to circumstances. If, on the other hand, the issue is legitimacy in a democratic sense, then the tone of international civil servants properly ought to be the ideologically inflated language - the wholesale adoption of metaphors taken from domestic democratic society - of 'international civil society'. Such an explanation denies nothing to the admirable achievements of

79 Elsewhere, I have referred to these elites in 'class' terms; see Anderson, 'Secular Eschatologies of the Internationalized New Class', supra note 38. Here in this article, I am deliberately using the term 'elites' to avoid the theoretical connotations of class; I think that one can make out the argument in conventional class theory, but I do not think it is necessary baggage for the argument of this article.

80 This seems to be at least partly the thinking of the Nobel Peace Prize Committee in awarding the prize to such groups as the ICBL. See the sceptical article by Sellars, 'The New Imperialists: Médécins sans frontières is at the Heart of the Modern Global Establishment', Spectator (London), 23 October 1999, at 26. 
many international NGOs, but does at least offer a reason why the praise has become so ideologically extravagant.

The process of legitimation is symbiotic and not merely parasitic, however. International NGOs, for their part, are happy to accept the accolade of 'international civil society', the voice of the people, and so on, for the obvious reason that it increases their power and authority within international organizations, international elites, and beyond. Why shouldn't an international NGO want to be described as the fundamental source of legitimacy for international organizations? It can only gain from the inflation of rhetoric. International organizations and international NGOs can be seen as locked in a romance, a passionately mutual embrace, offering each other love tokens of confirmations of legitimacy and eternal fealty, but, as with lovers everywhere, oblivious to the world outside and oblivious as to whether anyone else thinks that such mutual legitimations make either one any more 'legitimate'.

To be sure, none of these dark objections makes any difference if it were the case that international NGOs really are the authentic voices of democracy, really are authentic intermediaries of the 'people', and so really confer legitimacy on international organizations. If that were so, then even my view that genuine democracy at the level of the whole planet sufficient to grant legitimacy to 'strong' supranationalism is impossible might be overcome by the existence of democratic intermediaries. But this is implausible, for at least two reasons.

First, what I have termed in this paper 'international NGOs' are not very often connected, in any direct way, to masses of 'people'. International NGOs, in virtue of their role to operate globally rather than locally, are fundamentally elite organizations. There are exceptions, to be sure, but they are prototypically large religious affiliations; the Roman Catholic Church is the prototype of a genuinely global organization of civil society that is organized simultaneously locally and transnationally, drawing from the masses of the 'people', very rich and very poor and everything in-between. But one does not see international organizations falling over themselves to seek legitimacy from the Catholic Church or from any other church.

There are certain large secular exceptions, as well; Amnesty International is perhaps one, in that at least it has a large base membership. ${ }^{81}$ But that membership comes mostly from wealthy countries, and its membership even in those countries tends to be educated and at least middle class; Amnesty and the Catholic Church are not remotely in the same universe when it comes to the representativeness of their members. And in any case, the far more typical 'international' NGO of the kind whose approval and favour international organizations seek is much closer to the model of Human Rights Watch - a relatively small, highly professional, entirely elite organization funded by foundations and wealthy individuals in the Western

81 See the Amnesty International website at www.amnesty.org for more information on Amnesty's membership and composition. 
democracies, and having no discernible base outside international elites. ${ }^{82}$ This is not to denigrate Human Rights Watch or the vital work it does, but it would be the first to declare that its legitimacy is not based on democratic roots among the masses but on its fidelity to its own conception of the meaning of international human rights. The legitimacy, if any, it confers upon international organizations in particular circumstances is on account of their fidelity to Human Rights Watch's conception of the meaning of international human rights. It does not represent anyone other than itself and does not pretend to.

International NGOs collectively are not conduits from the 'people' or the 'masses' or the 'world citizenry' from the 'bottom up'. They are, rather, a vehicle for international elites to talk to other international elites about the things - frequently of undeniably critical importance - that international elites care about. The conversation is not vertical, it is horizontal. It has a worthwhile, essential function in making the world sometimes at least, a better place - but it does not reduce the democratic deficit.

Second, if the idea of 'international civil society' is drawn by an analogy ${ }^{83}$ to civil society in domestic society, then it bears noting that at least in the United States, with its vigorous and diverse civil society, civil society is not conceived of as being a substitute for democratic processes, let alone conveying democratic legitimacy. On the contrary, the glory of civil society is precisely that it is something different from democracy and democratic processes. The glory of civil society is not that it speaks with the authenticity of the 'people', the 'masses', the popular will, the general will, or with a single voice at all, but instead that organizations in civil society speak each for itself.

Put bluntly, the glory of organizations of civil society is not democratic legitimacy, but the ability to be a pressure group. Organizations in civil society do not share a common vision of the good, nor need concern themselves with the common good, in any holistic fashion at all if they choose not to. They have particular agendas and particular issues and particular constituencies. But for that very reason, they are not the voice of democracy and do not convey, at least in real democracies — rather than faux-legitimate systems like those of international organizations - democratic legitimacy. As David Rieff has aptly expressed it:

Human rights workers sometimes talk of their movement as an emblem of grass-roots democracy. Yet it is possible to view it as an undemocratic pressure group, accountable to no one but its own members and donors that wields enormous power and influence. For example,

82 See Human Rights Watch's website, www.hrw.org, for more information on membership and composition; see also its United States informational tax filing as a non-profit organization on Form 990, on file at the United States Internal Revenue Service or at the offices of Human Rights Watch, New York (but soon to be online through new tax regulations).

83 As earlier noted, however, I think this analogy is inappropriate, for the reason that I do not think that domestic society and international relations, however frequently termed 'international society' or the 'international community', are usefully construed in parallel. To put it another way, I think the idea of the 'international community' is to presume a false conclusion; I do not think it exists in any sense in which community means something in domestic society. It is a dangerously misleading metaphor, the metaphor that causes liberal internationalists to believe, for example, that intervening in Kosovo is not really war, it is merely an exercise in policework. 
would there have been a war in Kosovo without the human rights movement? As a supporter of the war in Kosovo, I applaud the result. As a democrat, I worry. ${ }^{84}$

Pressure groups, organizations of civil society, depend upon democracy and the rule of law, and reinforce those institutions as well, but they are not a substitute for them. The irony is that many of those who believe that they have discovered in 'international civil society' the elusive democratic connection would not for a moment imagine such a thing within their own, genuinely democratic, domestic societies: they would recognize them for precisely what they are, political pressure groups. This is not to deny the value of political pressure groups; at their best, they make all of society a better place, and the same is true of the world at large, the planet, but they are not a substitute for democracy. They speak for themselves, and so always leave open the question Rieff has posed, with admirable insouciance, "so who elected the NGOs?" ${ }^{85}$

\section{International NGOs, Civil Society, and Democratic Legitimacy}

This discussion has not strayed so far from the question of the landmines ban campaign as might be imagined. The interpretations of the political meaning of the ban campaign, and its legacies for the international system and lawmaking, held widely among international elites and expressed with considerable eloquence, especially, by the writers in To Walk Without Fear, presuppose an extensive ideology. To challenge the conclusions they reach about the legacies of the international ban campaign requires that one challenge the presumptions, often very large, which their ideologies make. I have endeavoured to do so by counterposing, in necessarily sketchy form, an alternative ideology, one which I suggest better fits the facts about international civil society and international organizations than the one prevalent among international elites.

I have further suggested that there are powerful motivational reasons among international elites themselves for why they would adopt a view of democracy and civil society that I doubt very much they would adopt with respect to domestic society. The point, therefore, is that the 'partnership' envisioned by international elites between international civil society, on the one hand, and sympathetic states and international organizations, on the other, is not necessarily what it seems. ${ }^{86} \mathrm{I}$ am a strong supporter of a comprehensive global ban on landmines, but I am a supporter

84 Rieff, supra note 68 , at 41.

85 David Rieff, speaking at a panel discussion on landmines and international civil society, Washington College of Law, American University, 25 February 1998.

86 I take it for granted that the position of sympathetic states in the landmines campaign is sufficiently close to that of international organizations and, more generally, supranationalism as to render a discussion of them separately in their relation to international NGOs unnecessary; the discussion would be much the same. 
explicitly on the basis of what the leaders of the landmines ban campaign are, namely, members of an emergent international elite. I am perhaps more strident in raising this concern than others, but I am not alone in having it; Larry Cox, a former Amnesty International staff member now at the Ford Foundation, has said:

Twenty years ago, when you went to a meeting at a human rights group, you saw all kinds of people. But these days, you usually find that most of the people there are either lawyers or human rights professionals. To me, the human rights movement has not been successful in capturing the imagination of a broad group of people - the way, whatever I may think of them, a strong civil-society group like the National Rifle Association has done. ${ }^{87}$

A ban on landmines is, to my mind, the morally and politically right thing to do, and I hope and, as an international NGO activist, strive hard to cause the United States to join the Ottawa Convention. But no matter how many non-governmental organizations across the globe adopt this position, they do not 'democracy' make. They - we - are pressure groups, political lobbying groups, and they do not confer democratic legitimacy, least of all upon the profoundly undemocratic organs of the international system. Even within domestic society, civil society and its organizations are not themselves the 'democratic process'; they are part of the pressures brought to bear on the outcomes of the democratic process. Organizations of civil society are by their nature particular, and lack the ability to confer general legitimacy. ${ }^{88}$

87 Quoted by Rieff, supra note 68, at p. 41.

88 It will be noted that this paper was drafted before the events at the Seattle World Trade Organization meeting. Those events have raised a serious breach within the emergent international elites I have described in this this paper, between at least some international NGOs and forces of global capitalism. The elite international human rights organizations occupy a peculiar position within that breach, both because they stand so assertively for internationalism and because the international human rights movement has relied so strongly on global capitalism to open up non-western societies to its proselytizing. But the analysis of the Seattle WTO meeting will to have to be another paper. 